\title{
Episodicity of structural flow in an active subduction system, new insights from mud volcano's carbonate veins - Scientific ocean drilling expedition IODP 366
}

\author{
Emanuelle Frery $^{1 *}$, Patricia Fryer ${ }^{2}$, Walter Kurz ${ }^{4}$, Ai Nguyen $^{3}$, Olivier Sissmann ${ }^{5}$, Tonguc \\ Uysal ${ }^{3}$, J. Zhao ${ }^{3}$ \\ ${ }^{1}$ CSIRO, 26 Dick Perry avenue, Kensington WA 6152 \\ ${ }^{2}$ Hawaii Institute of Geophysics and Planetology University of Hawai i at Mānoa 1680 East-West Road, POST \#514 \\ Honolulu, HI 96822 \\ ${ }^{3}$ School of Earth and Environmental Sciences, The University of Queensland, St Lucia QLD 4072 Australia ${ }^{4}$ Institute of \\ Earth Sciences, University of Graz, Heinrichstrasse 26, Graz A-8010, Austria \\ ${ }^{5}$ IFP Energies nouvelles 1 \& 4, avenue de Bois-Préau 92852 Rueil-Malmaison Cedex - France \\ * Correspondence: emanuelle.frery@csiro.au
}

\begin{abstract}
This study's goal is to understand the structural events and episodes of fluid flow recorded in calcium carbonate precipitation sampled in Mariana forearc serpentine mud volcanoes. Those active mounts provide a unique window to deep structural and fluid flow events affecting the subduction channel mélange zone and the subducted Pacific Plate.

To build a conceptual model of vein precipitations from the subduction zone to the mud volcanoes edifice, we unravelled the origin, timing, and mechanisms of those precipitations with a multidisciplinary study of calcium carbonate veins, from samples drilled in the flank of Fantangisña Seamount during the International Ocean Discovery Program (IODP) Expedition 366.
\end{abstract}

Structural analysis of the carbonate vein network revealed stages of precipitation and dissolution. The most ancient calcium carbonate minerals underwent high tectonic stress and several degrees of silicification. U-Pb dates ranged from Early Cretaceous to present day, recording potential pre-convergence events and calibrating an episodic building of the Mariana mud volcanoes from the start of the convergence to present day. The UCC-normalized LREE pattern, ${ }^{87} \mathrm{Sr} /{ }^{86} \mathrm{Sr}$ ratios ranging from 0.704977 to 0.705798 and $\delta^{18} \mathrm{O}$ signature 18.7 to 19.8 (\%, V-SMOW) of the veins indicate a mixed origin of the precipitated fluids influenced by the serpentine mud signature.

Those mud volcanoes were episodically built from the start of the subduction to present day in function of the forearc tectonic activity. They are complex systems internally composed of a fault network providing multiple circulation pathways that can be successively opened or closed. 
2 Brittle fault transmissivity varies through the seismic cycle (Sibson, 1994), the fluid

3 pressure evolution being controlled by fluid flow and rapid compaction (Byerlee, 1990;

4 Rice, 1992; Sleep \& Blanpied, 1994) or pressure solution crack sealing processes (Renard

5 et al., 2000; Gratier et al., 2002). Faults are complex zones, with internal variations of

6 lithology and architecture that are function of the fault evolution stage, i.e. from relay

7 zones to faulted rocks (Childs et al., 2009). These parameters also greatly influence fault

8 zone hydro-mechanical properties and behaviors (Faulkner \& Rutter, 2001).

9 Numerous U-Th radiogenic datings and isotopic studies of Quaternary calcium carbonate

10 veins precipitated within faults zones, have shown that those veins are a relevant proxy

11 for calibrating both tectonic and paleo-hydrothermal activity (Uysal et al., 2007; Dockrill \&

12 Shipton, 2010; Nuriel et al., 2017; Uysal et al., 2011; Frery et al., 2015; Vignaroli et al.,

13 2016). Recent U-Pb calcium carbonate geochronology applied to older calcium carbonate

14 veins increased the range of possible radiogenic datings up to Palaeozoic ages. Single

15 deformation events were successfully constrained (Roberts \& Walker, 2016; Ring \&

16 Gerdes, 2016; Nuriel et al., 2017) as well as complex deformation events in sequences of

17 orogenic forelands events (Hansman et al., 2018; Beaudoin et al., 2018).

18 Here, the challenge is to understand the origin of calcium carbonate precipitation events

19 recorded in Mariana forearc serpentine mud volcanoes as to better calibrate the seismic

20 cycle of this region. The samples examined are pebble veins embedded in serpentinite

21 mud and the veins' orientations cannot be directly related to given tectonic events (Fryer

22 et al., 2018, Fryer et al., 2020). In order to assess the cycles of calcium carbonate

23 precipitation in such a system, we need to unravel (i) the time-lapse, duration, recurrence 
and (ii) mechanisms of precipitation as well as (iii) the source of the precipitation fluid and the circulation trigger.

We undertook a structural, geochemical and radiogenic study of calcium carbonate veins sampled on the flank of Fantangisña Seamount during the International Ocean Discovery Program (IODP) Expedition 366 and proposed a conceptual model of the calcium carbonate vein precipitation from the subduction zone to the mud volcano edifice.

\section{Mariana forearc active mud volcanoes}

31 Mariana forearc serpentinite mud volcanoes (Figure 1A) provide a window to deep

32 structural and fluid flow events affecting the subduction channel mélange zone and the 33 subducted Pacific Plate. These active mud volcanoes are located between the trench and

34 the active volcanic arc on the eastern edge of the Philippine Sea plate, within $100 \mathrm{~km}$ west of the non-accretionary Mariana convergent margin (Uyeda \& Kanamori, 1979). Recent exploration of these mud volcanoes revealed varying thermo-dynamical conditions at different slab depths, as well as the mechanisms of material subduction and exhumation through deep-rooted faults, from the slab and subduction channel mélange zone to the sea floor. The Ocean Drilling Program (ODP) Leg 125 and Leg 195 (Fryer et al., 1992; Salisbury et al., 2002) drilled Conical and South Chamorro Seamounts located far

41 from the trench (about $78 \mathrm{~km}$ ) with a deep plate interface (up to 18-19 km), providing a window into warm $\left(\sim 350^{\circ} \mathrm{C}\right)$ subduction conditions. The IODP expedition 366 explored Asùt Tesoru, Fantangisña, and Yinazao Seamounts, located closer to the trench, respectively about $72 \mathrm{~km}, 62 \mathrm{~km}, 55 \mathrm{~km}$ to the west of the trench, with a shallower inferred subducted slab $18 \mathrm{~km}, 14 \mathrm{~km}, 13 \mathrm{~km}$ below the volcanoes summit and with temperatures of the slab-mantle interface below the above-mentioned three seamounts ranging from $\sim 250$ to $80^{\circ}$ (Fryer et al., 2018; 2020). While those mud volcanoes were 
informally known as Big Blue, Celestial and Blue Moon Seamounts, the IODP expedition

366 scientific party agreed on using their Chamorro names.

The seamounts are composed of unconsolidated flows of serpentine mud with ultramafic

51 clasts, mainly serpentinized mantle peridotite (Fryer \& Salisbury, 2006) and reveal active

52 fluid seepage of slab derived fluids (Fryer et al., 1999; 2006). This study focusses on

53 Fantangisña Seamount flank and summit drilling (Figure 1B) material sampled during IODP

expedition 366. This mud volcano lies at the northern edge of a north-western trending serpentine mud matrix.

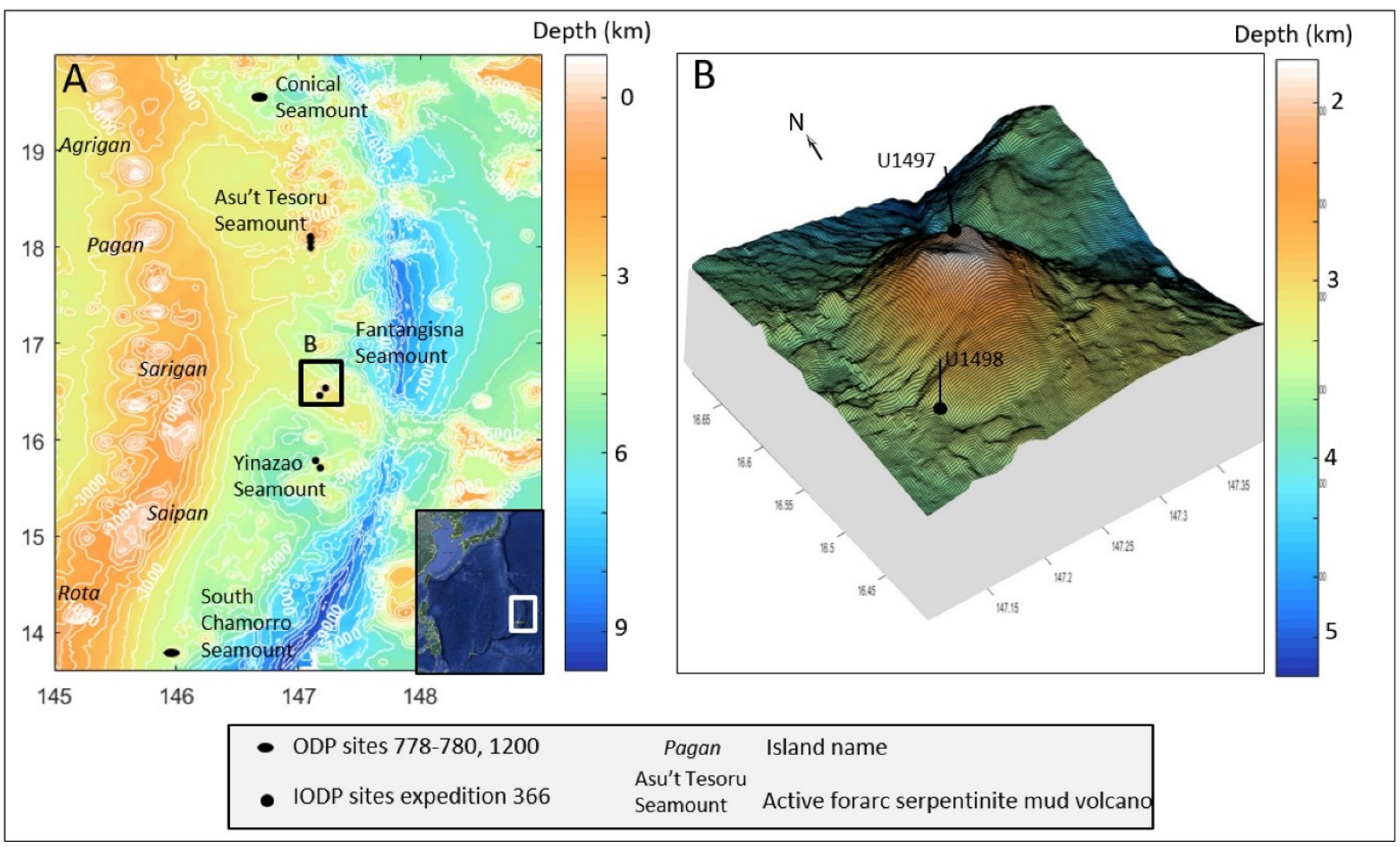

Figure 1. Bathymetry of the Mariana forearc showing the locations of the serpentinite mud volcanoes

61 dated with U-Pb method. (B.) Detailed bathymetry and location of IODP 366 sites on the flank and 62 summit of Fantangisña (Celestial) Seamount. 
64 The recovered material mainly consists of serpentinite mud containing lithic clasts derived

65 from the underlying forearc crust/mantle and the subducting Pacific plate slab. Clasts derived from the underlying forearc crust and mantle and the subducted slab form a major fraction of the recovered clasts at the studied sites: U1497 (Fantangisña summit) and U1498 (Fantangisña flank). Site U1497 drilling reached depths at Fantangisña Seamount summit (Figure 1B) between 2018.30 and $2019.24 \mathrm{mbsl}$, recovering $42.38 \mathrm{~m}$ of material. Site U1498 is located on the flank of the edifice, drilling between 3284.70 and $3496.21 \mathrm{mbsl}$ and recovering $103.41 \mathrm{~m}$ of core (Fryer et al., 2017).

This work focuses on carbonate veins sampled at the contact between a metabasite and a chert limestone (Figure 2), in cores U1498A 3R 2W, U1498B-8R and U1498B-21R through U1498B-23R. This hard rock sequence is embedded in pebbly serpentinite mud. Following a macroscopic structural analysis of the vein network on-board (Fryer et al., 2017; 2018), the various carbonate vein families were sampled so as to describe the mineral growth mechanisms and diagenesis processes. Polished thin sections and slabs were respectively imaged with a petrographic microscope and microbeam X-Ray Fluorescence (XRF) (Bruker M4 TORNADO ${ }^{\mathrm{TM}}$ ) imaging. Scanning electron microscopy (SEM) picking of the mineral content led to subsamples from 7 rock slabs for U-Pb absolute dating by laser-ablation. 

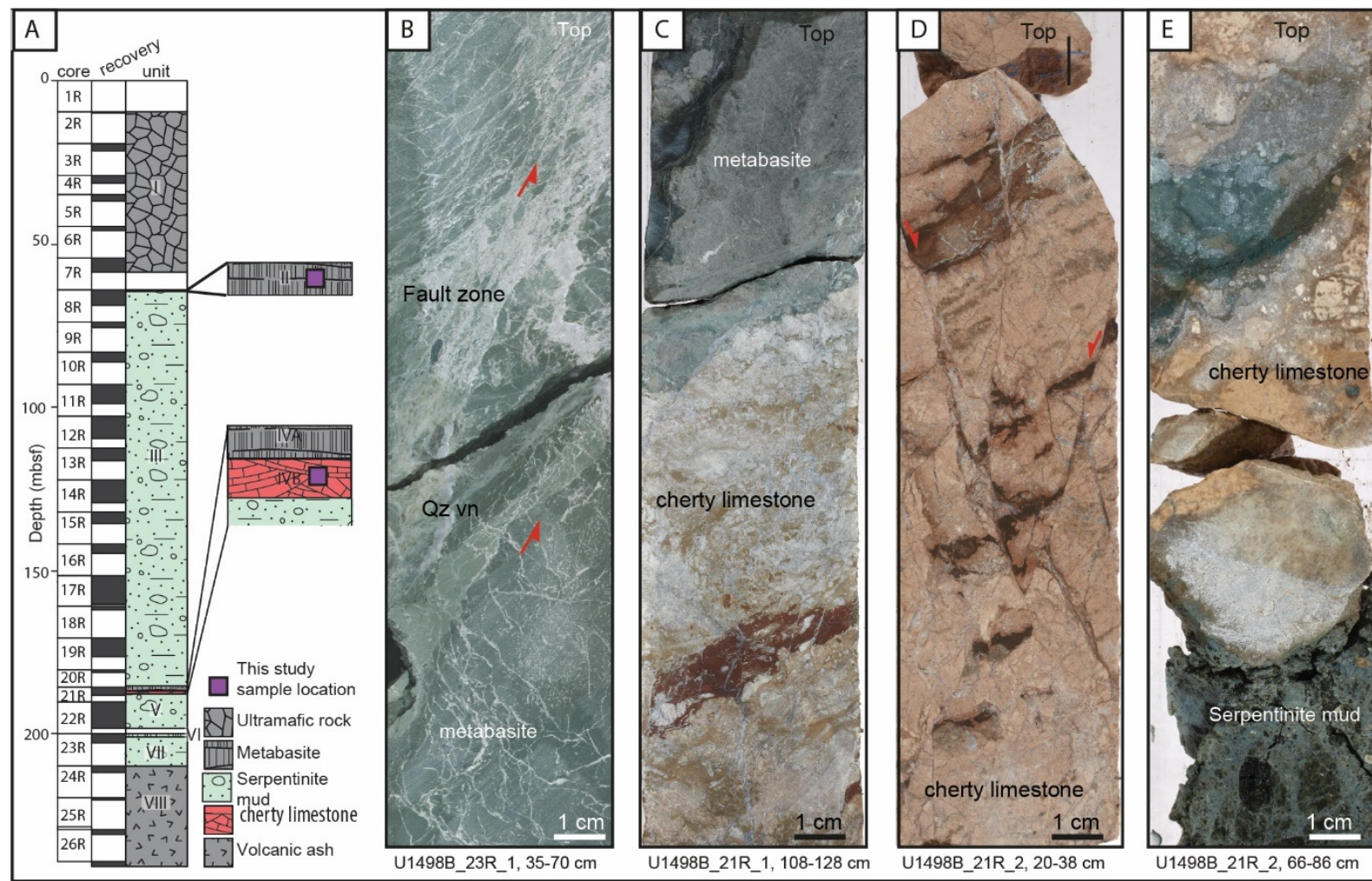

Figure 2. Location and lithology of this study carbonate vein samples (A) location of the metabasite and metasediment series within the pebbly serpentine mud on the example of Hole U1498B. (B-E) Close up pictures of this series.

\subsection{Trace elements}

Trace elements of calcium carbonate veins of polished slabs were measured using an ASI

RESOlution $193 \mathrm{~nm}$ excimer UV ArF laser ablation system with a dual-volume Laurin

Technic ablation cell integrated with a Thermo iCap RQ quadruple mass spectrometer at

The University of Queensland Centre for Geoanalytical Mass Spectrometry, Radiogenic

Isotope Facility, following Ubide et al. 2019's protocol with some modifications for spot analysis. To eliminate contaminants from lapidary process, the polished slabs were thoroughly cleaned with soap solution, followed by MilliQ water with assistance of a sonication, and dried overnight at $60^{\circ} \mathrm{C}$ on a hot plate before loading into the ablation cell. The mass spectrometer was tuned by scanning a NIST612 glass reference material with a laser parameters of $50 \mu \mathrm{m}$ spot size, a $3 \mu \mathrm{m} / \mathrm{s}$ speed, and a $10 \mathrm{~Hz}$ repetition rate, to achieve an optimal condition of high sensitivity and low double charge and oxide rates. 
Sample ablation was performed with a laser beam of $3 \mathrm{~J} / \mathrm{cm}^{2}$, a spot size of $100 \mu \mathrm{m}$, and a repetition rate at $10 \mathrm{~Hz}$. The ablated sample aerosols were directed to a funnel and carried to the mass spectrometer by a mixture of ultrapure He (350 ml/min), $\operatorname{Ar}(950$ $\mathrm{ml} / \mathrm{min}$ ) gases. A minor amount ( $5 \mathrm{ml} / \mathrm{min}$ ) of $\mathrm{N}_{2}$ gas was also added to the gas system for boosting transport efficiency and elemental intensity. The acquisition time for each spot was $20 \mathrm{~s}$ for the baseline, $25 \mathrm{~s}$ for sample ablation, and 10 s for system washout. The sample spots were run in between the glass standard NIST 614 which was used as a calibration standard for data reduction using lolite 3.6 (Woodhead et al., 2008). Calcium was assumed to be $40 \%$ in the samples and used as an internal standard for data normalization. Some of NIST 614 spots were processed as unknowns during data reduction and their elemental concentrations agree well with certified values (errors of rare earth elements, $\mathrm{Rb}, \mathrm{Sr}, \mathrm{Ba}$, Th and $U$ within $5 \%$ and of other elements $~ 10 \%)$.

\section{2. $\mathrm{U} / \mathrm{Pb}$ dating}

$\mathrm{U} / \mathrm{Pb}$ data were obtained from Nu II instrument Multi-collector Inductively Coupled Plasma Mass Spectrometer coupled with the same laser ablation system. The sample zone with high $\mathrm{U}$ and low $\mathrm{Pb}$, based on the trace element data, were ablated at a spot size of $100 \mu \mathrm{m}$, a repetition rate of $10 \mathrm{~Hz}$ and a fluency of $3 \mathrm{~J} / \mathrm{cm}^{2}$. The data were acquired for $20 \mathrm{~s}$ for the baseline, 30s for sample ablation, and 10s for system washout before the next spot analysis. The induced sample aerosols were carried by ultrapure $\mathrm{He}$ and $\mathrm{Ar}$ gases and a trace amount of $\mathrm{N}_{2}$ gas to stabilize the aerosol input to the plasma. The ${ }^{238} \mathrm{U}$ was measured with Faraday cups and ${ }^{208} \mathrm{~Pb},{ }^{207} \mathrm{~Pb},{ }^{206} \mathrm{~Pb}$, and ${ }^{204} \mathrm{~Pb}$ were measured on four ETP discrete-dynode electron multipliers. We have obtained $~ 150$ spot analyses on in-house calcite standards (AHX-1A and ASH15E), 270 spot analyses on the selected samples and 80 spot analyses on NIST-614 glass standard for U-Pb isotope analyses. U-Pb isotopic 
ratios and their uncertainties were calculated using lolite 3.6 (Paton et al. 2010).

${ }^{238} \mathrm{U} /{ }^{206} \mathrm{~Pb}$ and ${ }^{207} \mathrm{~Pb} /{ }^{206} \mathrm{~Pb}$ ratios were corrected for any instrument drifts and isotopic fractionation (but not corrected for down-hole fractionation) using the glass standard NIST 614 values. The corrected U-Pb isotopic data of calcite standard AHX-01A was plotted on Tera-Wasserburg concordia using an Isoplot software to calculate its age. The "true" age of this standard is $209.8 \pm 1.3 \mathrm{My}$ (it is the average age obtained by being multi-calibrated against ASH-15E, with age of 3.001 $\pm 0.0012 \mathrm{My}$ by ID-TIMS). An offset factor of the measured age vs. true age of $\mathrm{AHX}-1 \mathrm{~A}$ was used to normalise the ${ }^{238} \mathrm{U} /{ }^{206} \mathrm{~Pb}$ ratios of the unknowns, including ASH-15E. The normalised U-Pb ratios of all samples and standards were regressed on Tera-Wasserburg concordia to achieve the ages. The ASH15E gives an age of 3.021 $\pm 0.051 \mathrm{My}$, within an error of the published value (Nuriel et al., 2017), suggesting the cross-calibration is reliable.

A careful check of those data refined the $\mathrm{U} / \mathrm{Pb}$ dating dataset by laser-ablation to four samples. The samples' IODP references are U1498B 8R $1 \mathrm{~W}(10$ to $12 \mathrm{~cm})$, U1498B 21R $2 \mathrm{~W}(6$ to $10 \mathrm{~cm})$, U1498B $21 \mathrm{R} 2 \mathrm{~W}(26$ to $29 \mathrm{~cm}), \mathrm{U} 1498 \mathrm{~A} 3 \mathrm{R} 2 \mathrm{~W}(10$ to $12 \mathrm{~cm})$. To simplifies the text, they are here respectively called $A 5, A 1, A 7$ and $D 5$. The other samples have $U$ content too low for analysis $(\mathrm{U}<0.01 \mathrm{ppm})$ and/or $\mathrm{U} / \mathrm{Pb}$ ratios so small $\left({ }^{238} \mathrm{U} /{ }^{206} \mathrm{~Pb}<<10\right)$ that they imply huge amount of common Pb. In comparison, zircons typically have uranium content of $\sim 50-500 \mathrm{ppm}(1000-10,000$ times higher than most calcites) and $\mathrm{U} / \mathrm{Pb}$ ratios far in excess of 10 for samples younger than $50 \mathrm{My}$.

\subsection{Srontium, carbon and oxygen isotopes}

Strontium isotope $\left({ }^{87} \mathrm{Sr} /{ }^{86} \mathrm{Sr}\right.$ ratios) analysis were performed at the Radiogenic Isotope Facility, University of Queensland, Australia. $\sim 10 \mathrm{mg}$ of sample powder was obtained from each calcite vein and digested in weak acetic acid to extract $\mathrm{Sr}$ from the carbonate 
146

147

phase. The sample solution went through a Sr separation following standard cation exchange column procedure as detailed in Wei et al (2014). 87Sr/86Sr was measured using a Nu Plasma I multi-collector inductively-coupled plasma mass spectrometry (MC-ICPMS). A standard SRM 987 was measured at every five samples and used as an external calibration. Long-term repeated measurement of the SRM 987 standard yields a mean $87 \mathrm{Sr} / 86 \mathrm{Sr}$ value of $0.710250 \pm 0.000032(2 \sigma)$.

The $\delta^{13} \mathrm{C}$ and $\delta^{18} \mathrm{O}$ isotopic composition of carbonate samples were measured the NGL Geochemistry laboratory at CSIRO Energy on a Thermo MAT253 IRMS, coupled with a dual inlet connected to a Gasbench II. For each sample, a few milligrams of powder was placed in a glass vial capped with a septum, which was then flushed with Helium. Orthophosphrous acid was then injected into the flushed vial, dissolving the carbonate powder and releasing $\mathrm{CO}_{2}$ within the vial. The $\mathrm{CO}_{2}$ gas was then sampled automatically from the vial headspace by a syringe and sent to the IRMS, where isotopes abundances were measured on masses $45 / 44$ ( for $\delta^{13} \mathrm{C}$ ) and $46 / 44\left(\delta^{18} \mathrm{O}\right)$. Values of $\delta^{18} \mathrm{O}$-PDB were converted to $\delta^{18} \mathrm{O}$ V-PDB to $\delta^{18} \mathrm{O}$ V-SMOW according to $\delta^{18} \mathrm{O}(\mathrm{V}-\mathrm{SMOW})=$ $1.03092\left[\delta^{18} \mathrm{O}(\mathrm{V}-\mathrm{PDB})\right]+30.92$ (Coplen 1995).

\section{Results}

\subsection{Structural analysis}

On-board structural analysis of the cores revealed simple to multiple veins within the ultramafic clasts. Those veins are mainly composed of serpentine minerals and occasionally of carbonate, silicate or brucite (Fryer et al., 2018). Carbonate and silicate veins were mostly recovered within cataclasites and fault zones that cross-cut a unit composed of a metabasite and a cherty limestone embedded in the serpentinite mud (Figure 2). A dense network of millimetre- to centimetre-wide veins cross-cut the metamorphosed volcanic rock, especially around a normal fault zone located in U1498B-23R-1 (Figure 2B). Above it, a primary contact, dipping at $5^{\circ}$ to $30^{\circ}$, is preserved 
172 between the metabasite and the metamorphic limestone (Figure 2C); the latter is

173 brecciated (Figure 2D,E) and subsequently sheared along conjugate high-angle normal

174 faults.

175 Multi-elemental XRF mapping and SEM analyses of the polished slabs A5, A1, and A7

176 outline several composite veins made of calcium and silicates (Figure 3, Table 1, Table

177 2,Table 3). Three vein sets on A5 (Figure 3A) show a progressive silicification of the

178 primary calcium carbonate from dominant calcium carbonate in vein v1 (> 50\% CaO, Table

179 1) to dominant silica in vein $v 3\left(>50 \% \mathrm{SiO}_{2}\right.$,Table 1$)$. Two types of veins were imaged on $\mathrm{A} 1$

180 (Figure 3B). Wide $(>0.5 \mathrm{~cm})$ calcium carbonate veins ( $1,>90 \% \mathrm{CaO}$, Table 2$)$ are

181 brecciated and displaced along conjugate high-angle faults. A few millimetre ( 0.5-1 mm)

182 silica dominated veins ( $22,>50 \% \mathrm{SiO}_{2}$,Table 2$)$ are scattered along the fault planes and

183 joints located at the edges of v1 displaced segments. In the case of sample A7 (Figure 3C),

184 patches of calcium/silicate composite veins are observable rather than proper veins. This

185 sample matrix is mainly composed of silica $\left(>60 \% \mathrm{SiO}_{2}\right.$, Table 3$)$ and the composition of the

186 patches highly varies from calcium carbonate (>90\% CaO, Table 3 ) to silica ( $>90 \%$

$187 \mathrm{SiO}_{2}$,Table 3). 

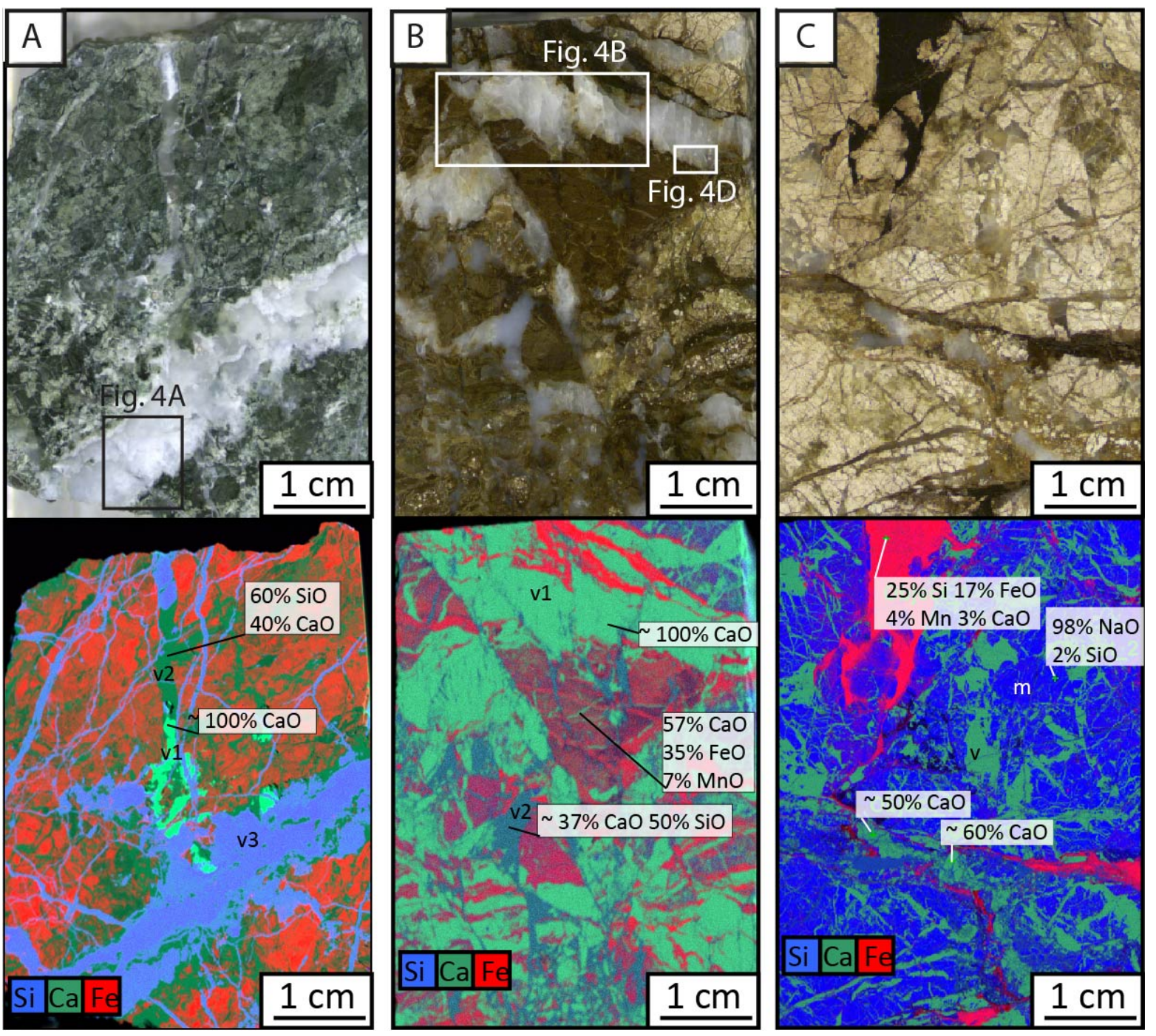

189 Figure 3. Macroscopic petrology (top) and microbeam X-Ray Fluorescence (XRF) (Bruker M4

190 TORNADO TM) imaging (bottom) of the vein network of samples (A) U1498B 8R 1W(10 to $12 \mathrm{~cm}$ ),

191 (B) U1498B $21 R 2 W(6$ to $10 \mathrm{~cm})$, (C) U1498B $21 \mathrm{R} 2 \mathrm{~W}(26$ to $29 \mathrm{~cm})$. In this study those IODP samples

192 are respectively recalled $\mathbf{A 5}, \mathbf{A} 1$ and $\mathbf{A} 7 . \mathrm{v}$ stands for vein and $\mathbf{m}$ for matrix. 


\begin{tabular}{|l|c|c|c|c|c|}
\hline Analysis & A5-1-1 & A5-1-2 & A5-1-2 & A5-2-3 & A5-3-1 \\
\hline Location & v3 & v2 & v2 & v1 & v1 \\
\hline Composition in norm. wt\% of oxides & \\
\hline Na2O & 9.3 & 0.9 & 9.7 & & \\
\hline SiO2 & 53.8 & 15.0 & 54.9 & 14.0 & 12.6 \\
\hline $\mathrm{CaO}$ & 35.0 & 60.0 & 33.6 & 56.3 & 59.1 \\
\hline $\mathrm{Cr} 2 \mathrm{O} 3$ & 0.9 & & & & \\
\hline Al2O3 & & 6.6 & & 7.3 & 7.0 \\
\hline SO3 & & 17.5 & 1.3 & 22.4 & 21.3 \\
\hline MnO & & & & & \\
\hline FeO & & & & & \\
\hline Total & 99.0 & 100.0 & 99.5 & 100.0 & 100.0 \\
\hline
\end{tabular}

200 *v stands for "vein" and $m$ for "matrix"

201 Table 2. Electron microprobe analyses of the veins, sample A1 [U1498B 21R 2 W (6 to $10 \mathrm{~cm})$ ]

\begin{tabular}{|l|c|c|c|c|}
\hline Analysis & A1-2-5 & A1-2-9 & A1-3-4 & A1-3-5 \\
\hline Location & v1 & v1 & v2 & v2 \\
\hline \multicolumn{4}{|l|}{ Composition in norm. wt\% of oxides } \\
\hline $\mathrm{Na2O}$ & & & 8.0 & 9.0 \\
\hline $\mathrm{SiO} 2$ & 3.2 & 1.3 & 53.1 & 51.7 \\
\hline $\mathrm{CaO}$ & 95.7 & 98.6 & 37.9 & 38.4 \\
\hline $\mathrm{Cr} 2 \mathrm{O} 3$ & & & & \\
\hline $\mathrm{Al} 2 \mathrm{O} 3$ & & & & \\
\hline $\mathrm{SO} 3$ & & & & \\
\hline $\mathrm{MnO}$ & & & 1.0 & 1.0 \\
\hline FeO & & & & \\
\hline Total & 98.9 & 100.0 & 100.0 & 100.0 \\
\hline
\end{tabular}

203 *v stands for "vein" and $m$ for "matrix"

204 Table 3. Electron microprobe analyses of the veins, sample A7 [U1498B 21R 2 W (26 to $29 \mathrm{~cm})$ ]

\begin{tabular}{|c|c|c|c|c|c|}
\hline Analysis & A7-1 & A7-2 & A7-2-3 & A7-2-4 & A7-1-11 \\
\hline Location & v & v & $\mathrm{m}$ & $\mathrm{m}$ & $\mathrm{v}$ \\
\hline \multicolumn{6}{|c|}{ Composition in norm. wt\% of oxides } \\
\hline $\mathrm{Na} 2 \mathrm{O}$ & 12.1 & 11.1 & & 8.0 & 0.91075 \\
\hline $\mathrm{SiO} 2$ & 51.5 & 51.7 & 93.9 & 65.2 & 6.45033 \\
\hline $\mathrm{CaO}$ & 32.9 & 27.1 & & 7.3 & 92.6389 \\
\hline $\mathrm{Cr} 2 \mathrm{O} 3$ & 1.1 & 0.9 & & & \\
\hline $\mathrm{Al} 2 \mathrm{O} 3$ & & & & & \\
\hline SO3 & & & & & \\
\hline $\mathrm{MnO}$ & 2.4 & 7.7 & & 5.8 & \\
\hline $\mathrm{FeO}$ & & & 1.5 & 13.7 & \\
\hline Total & 100.0 & 98.5 & 95.4 & 100.0 & 100.0 \\
\hline
\end{tabular}


207 The primary calcium carbonate minerals (Figure 4) are elongated to fan-shaped and highly

208 damaged with cataclasite and dissolution features. For instance, the calcites of

209 mineralisation stage $\mathrm{v} 1$ of sample A5 are fractured perpendicularly to the mineral growth

210 direction and v2 finer mineralisation grew in the interstices (Figure 4A). Stylolite features

211 are commonly observed in sample A1 veins (Figure $4 B, C$ ), indicating episodes of pressure

212 dissolution. The shape of the primary minerals $\mathrm{v} 1$ of $\mathrm{A} 1$ can be identified as mainly

213 fan-shaped (Figure 4B, C, D) with millimetre lengths. Those calcium carbonate minerals are

214 highly damaged, striated or fractured, and embedded in v2 mineralisation (Figure 4B, E).
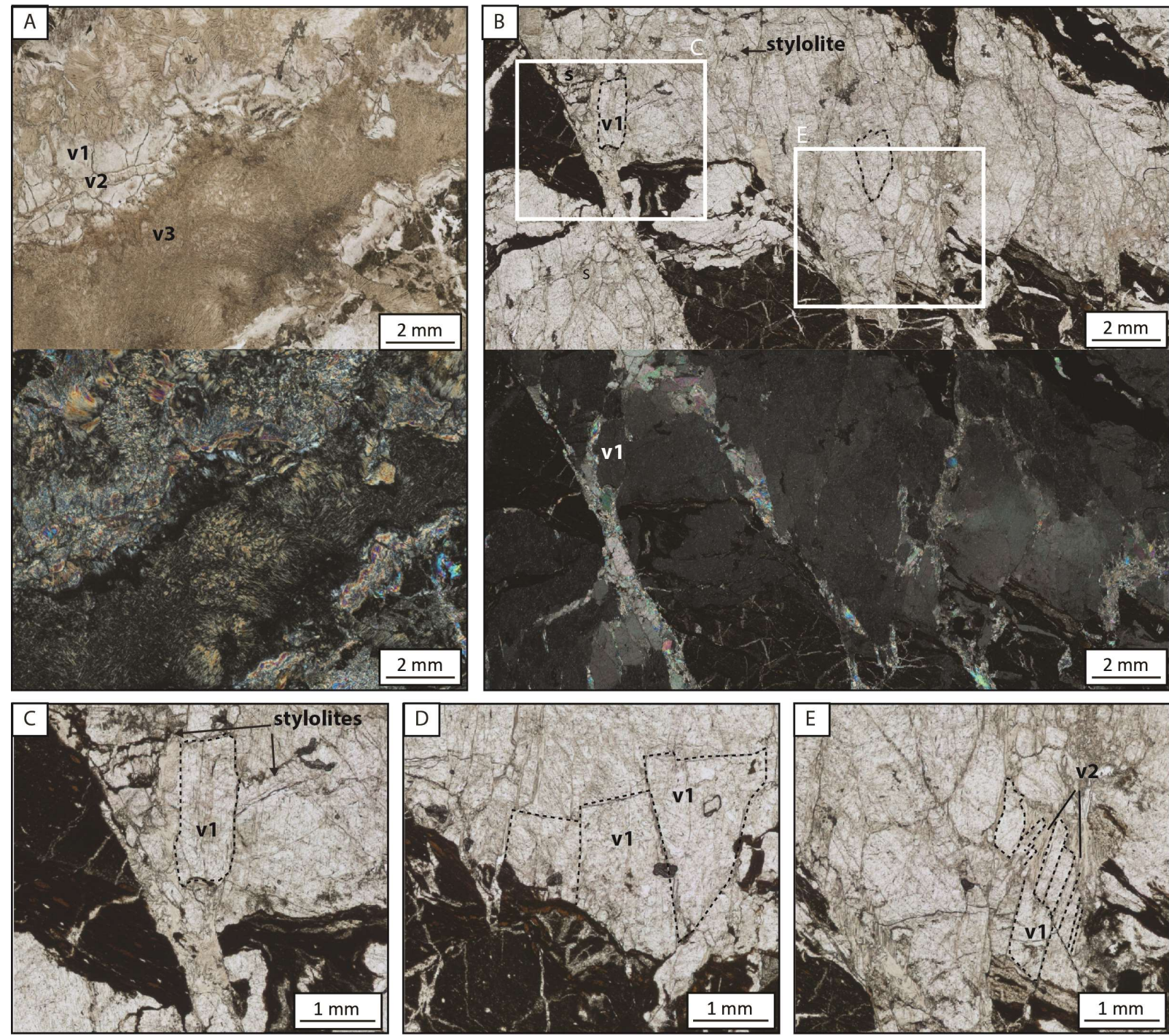

216 Figure 4. Optical evidence of primary mineral growth, dissolution and structural features in 217 carbonate veins. 
The locations of A, B (top) and D (bottom centre) are given on Figure 3 and are close-ups of areas on samples A5 [U1498B 8R 1W(10 to $12 \mathrm{~cm})$ ] and A1 [U1498B 21R 2W(6 to $10 \mathrm{~cm})$ ], the vein names v1 to v3 are also indicated on Figure 3. Some of the primary calcium carbonate minerals are outlined in dashed black on 4B to E. The chemical compositions are electron microprobe analysed

\subsection{Rare Earth Elements}

The entire Rare Earth Element (REE) dataset measured on each sample was processed

with the Mathematical computing software Matlab ${ }^{\circledR}$ developed by MathWorks as to extract a dominant trend per sample. The majority of the measured sampling spots shows a similar trend with few curves scattered up to a few orders of magnitude away from the main data package (A1 example, Figure 5A). Sample A4 (Figure 5B), sampled in cherty limestone material as sample $A 1$, shows a differential REE trend from the main calcium
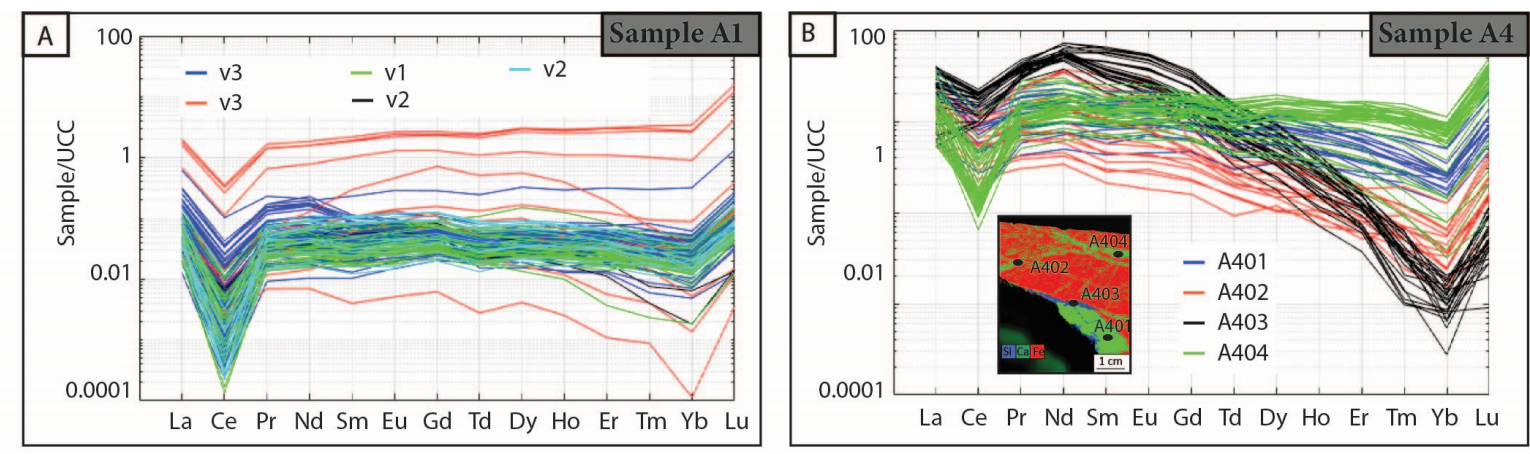

Figure 5. Examples of UCC-normalized REE patterns of each sampling point in the case of (A.) sample A1 data extracted in the veins v1, v2 and v3 localized fig.3 and (B.) sample A4 [366-U1498B-21R-2-W (26 to 29-cm)] with sampling point located on an X-Ray Fluorescence (XRF) image compiling $\mathrm{Si}, \mathrm{Ca}$ and $\mathrm{Fe}$ elements, the veins are composed of $\mathrm{Si}$ and $\mathrm{Ca}$. The first light six elements ( $\mathrm{La}, \mathrm{Ce}, \mathrm{Pr}, \mathrm{Nd}, \mathrm{Sm}$ and $\mathrm{EU}$ ) are called LREEs in this article and the 8 heavy elements (Gd, $\mathrm{Tb}, \mathrm{Dy}, \mathrm{Ho}, \mathrm{Er}, \mathrm{Tm}, \mathrm{Yb}$, and Lu).are called HREEs. Ample A4 too low uranium contant to be dated The upper continental crust (UCC-)-normalized REE pattern of this study's carbonate veins

241 vary strongly. The patterns show a main hydrothermal and/or seawater signature; with a 
242 minor influence from the serpentine mud (Figure 6). The 6 LREEs of both A1 and A7 match

243 the Pacific deep-water pattern with REEs low abundance and pronounced negative Ce but

244 without Eu anomalies. Sample A7's HREEs then remarkably well fit the hydrothermal fluids

245 curve whereas sample A1's HREEs fall between those of seawater and hydrothermal

246 fluids, except for a strong enrichment in Lu which is common in all studied carbonates. D5

247 REE tendency slightly correlates with the hydrothermal fluid curve, with a deeply

248 attenuated Eu positive anomaly ( $\sim$ two orders of magnitude lower). A5 shows the lowest

249 REE values of this study dataset. 


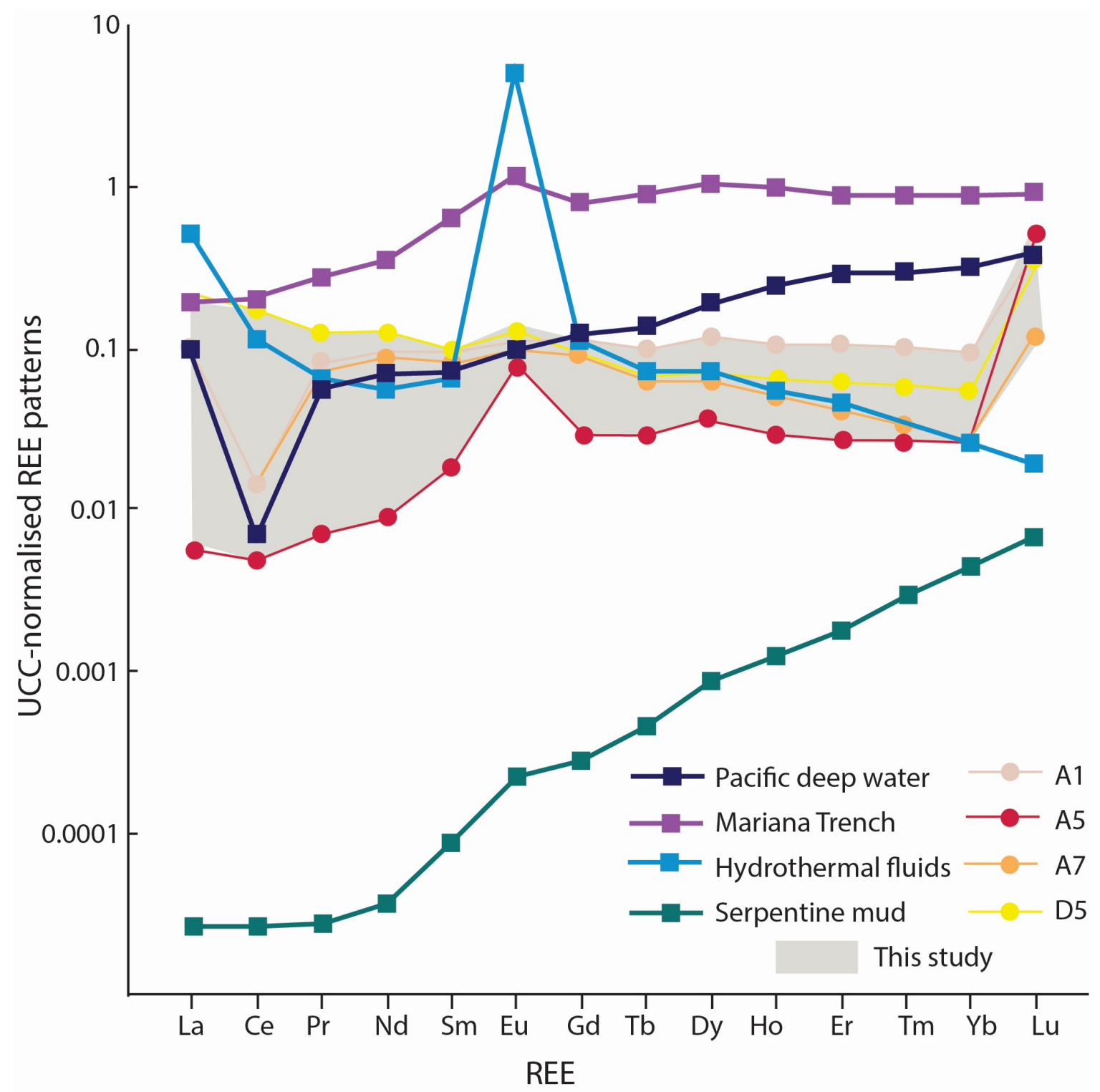

251 Figure 6. UCC-normalized REE patterns of this study carbonate veins samples, serpentine mud, 252 present-day marine sediments and seawater.

253 The purple, dark blue, light blue and green curves respectively show the REE distributions of the 254 Mariana Trench (Liyan et al., 2003), Pacific deep water $(\times 106$ for seawater) (Alibo and Nozaki 1999), 255 hydrothermal fluids ( $\times 106$ for fluids) (Douville et al. 2002), and serpentine mud (Kodolányi et al. 2011). The data are UCC normalized based on Taylor and McLennan $(1985,1995)$ (after Jiang et al. 257 2018).

\subsection{Srontium, carbon and oxygen isotopes}

260 The ${ }^{87} \mathrm{Sr} /{ }^{86} \mathrm{Sr}$ ratios fit the narrow range $0.704977\left(+/-7^{*}-10^{-6}\right)$ to $0.705798\left(+/--10^{-6}\right)$

261 (Table 4). Those values (Figure 7) lie closer to the Mariana extrusive volcanic and 
263 ocean drilling expeditions (DSDP leg 6, Leg 20 and ODP Leg 199; Ito and Stern 1986) and

264 the mean seawater trends (Spooner et al., 1976; Veizer et al., 1999). However, $\delta^{18} \mathrm{O}$

265 ranging from 18.7 to 19.8 (V-SMOW) \%o (Table 4) fit better with the seawater and

266 sediment $\delta^{18} \mathrm{O}$ signatures.

267 Table $4 .{ }^{87} \mathrm{Sr} /{ }^{86} \mathrm{Sr}, \delta^{13} \mathrm{C}\left(\%\right.$, V-PDB) and $\delta^{18} \mathrm{O}(\%$, V-SMOW) stable isotope analyses of this study 268 carbonate veins

\begin{tabular}{|r|l|r|r|r|r|r|r|}
\hline Sample & \multicolumn{1}{|c|}{ Reference } & ${ }^{87} \mathrm{Sr} /{ }^{86} \mathrm{Sr}$ & $\pm 2 \sigma$ & $\begin{array}{c}\delta^{13} \mathrm{C} \\
(\% \circ \mathrm{V}-\mathrm{PDB})\end{array}$ & $\pm 2 \sigma$ & $\begin{array}{c}\delta^{18} \mathrm{O} \\
(\% \text { V-SMOW) }\end{array}$ & $\pm 2 \sigma$ \\
\hline A1 & U1498B 21R 2W $(6$ to $10 \mathrm{~cm})$ & 0.705350 & $4.8 \mathrm{E}-06$ & 2.0 & $1 \mathrm{E}-01$ & 19.1 & $2 \mathrm{E}-01$ \\
\hline A4 & U1498B-21R-2W $(26$ to $29 \mathrm{~cm})$ & 0.705252 & $5.1 \mathrm{E}-06$ & n.m. & n.m. & n.m. & n.m. \\
\hline A5 & U1498B 8R 1W $(10$ to $12 \mathrm{~cm})$ & 0.705144 & $1.4 \mathrm{E}-05$ & 1.0 & $1 \mathrm{E}-01$ & 19.8 & $2 \mathrm{E}-01$ \\
\hline A7 & U1498B 21R 2W $(26$ to $29 \mathrm{~cm})$ & 0.705347 & $6.2 \mathrm{E}-06$ & 2.0 & $1 \mathrm{E}-01$ & 19.5 & $2 \mathrm{E}-01$ \\
\hline B11 & U1497B 7F1 2W $(43$ to $47 \mathrm{~cm})$ & 0.705114 & $7.3 \mathrm{E}-06$ & 3.1 & $1 \mathrm{E}-01$ & 19.5 & $2 \mathrm{E}-01$ \\
\hline D4 & U1496A 1F 2W $(31$ to $32 \mathrm{~cm})$ & 0.704977 & $7.0 \mathrm{E}-06$ & n.m. & n.m. & n.m. & n.m. \\
\hline D5 & U1498A 3R 2W $(0$ to $3 \mathrm{~cm})$ & 0.705798 & $6.8 \mathrm{E}-06$ & 2.2 & $1 \mathrm{E}-01$ & 18.7 & $2 \mathrm{E}-01$ \\
\hline
\end{tabular}

270 *n.m. stands for "not measured" 


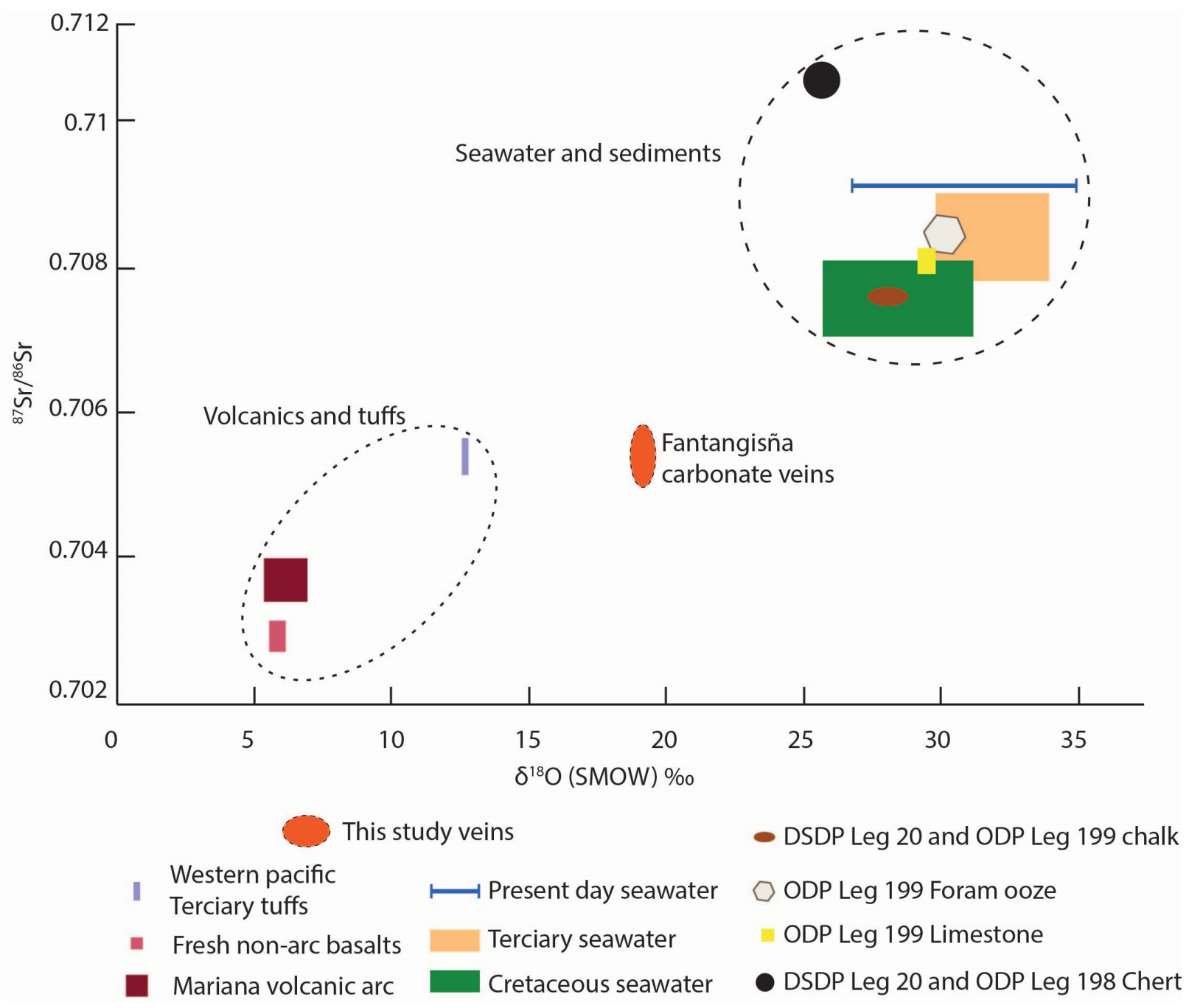

272 Figure $7 .{ }^{87} \mathrm{Sr} /{ }^{86} \mathrm{Sr}$ ratios vs. function of $\delta^{18} \mathrm{O}$ signatures

273 DSP Leg 20 and ODP Legs 198/199 drill Sites are located on the subducted Pacific Plate and targeted

274 the subducted sedimentary pile, see Ito and Stern (1986) for additional details.

$276 \mathrm{U}-\mathrm{Pb}$ absolute dating of the calcium carbonate veins of samples A1, A7 and D5 (Figure 8)

277 indicate Late Eocene to Quaternary precipitation of the calcium carbonate veins,

278 respectively $8.2(+/-3.4), 19(+/-21)$ and $25(+/-11)$ My. The uncertainty on those dates is

279 high, due to the huge amount of common Pb. Sample A1 carbonate veins are the youngest

280 with a post Tortonian age, whereas sample D5 veins are the oldest, Bartonian to

281 Serravallian. Given the uncertainty on sample A7's laser-ablation U-Pb dating, this sample's veins precipitation can only be restricted to late Eocene to present day. 
283 The carbonate veins of sample A5 precipitated 82 (+/-38) My ago. These veins have hence

284 formed during Early Cretaceous (120 My) to Late Cretaceous (44 My) times. This sample

285 contains by far the oldest of the here-investigated carbonates, even when considering the

286 large uncertainties of these ages.



288 Figure 8. U-Pb absolute dating by laser-ablation for four selected samples

\section{Discussion}

291 We here discuss an episodic formation of the Mariana mud volcanoes from the

292 subduction initiation to present day (Figure 9). Mariana convergence started $~ 50$ My ago

293 (Fryer et al., 1990; Mrozowski \& Hayes, 1980), and numerous extensional faults accommodated the primary forearc spreading (Stern, 2004), which initiated pathways for 
slab-derived fluids and materials of the subducting plate as well as of the

supra-subduction mantle to rise from the subduction channel mélange zone to the seafloor (Wheat et al., 2020), where the mud volcanoes formed (Figure 9A).

The ages of this study's carbonate veins range from Early Cretaceous to present day

(Figure 8) and have recorded fluid circulation in potentially four different extensional metabasalts did not show the same deformation and vein formation (Figure $2 \mathrm{C}$ ), which

systems respectively a) pre-subduction, on a plate seamount before it was subducted b) in the Mélange zone, pre-exhumation, c) within the forearc fault system, or d) within a mud volcano edifice.

The samples A1, A7 and D5 late Eocene to Quaternary ages are contemporaneous with the mud volcanism and could be related to either the exhumation process through the forearc normal fault system or precipitation processes within the mud volcano structure (Figure 9). Shearing and cataclastic structures and stylolites observed on-board and in A1, A5, and A7 cases (Figure 2, Figure 4, Fryer et al., 2018) show that the samples underwent high tectonic stress and pressure conditions.

\section{Sample A5 U-Pb ages, ranging from Early Cretaceous (120 My) to Lutetian (41.2 My)} cannot support a specific tectonic event directly linkable with the carbonate veins precipitation. However, those veins clearly precipitated before or during the early stages of exhumation. Many extension stages could have affected these rocks before the exhumation (Figure 9), from the initial setting up on a volcanic island or a seamount to the slab faulting in the flexural zone (Funnell et al., 2017) or the edifice deformation upon subduction. The vein system affecting the metabasite is dense and well localized within this domain (Figure 2B). Even the cherty limestone in primary contact with the supports localized deformation and hydrothermal fluid flow. 

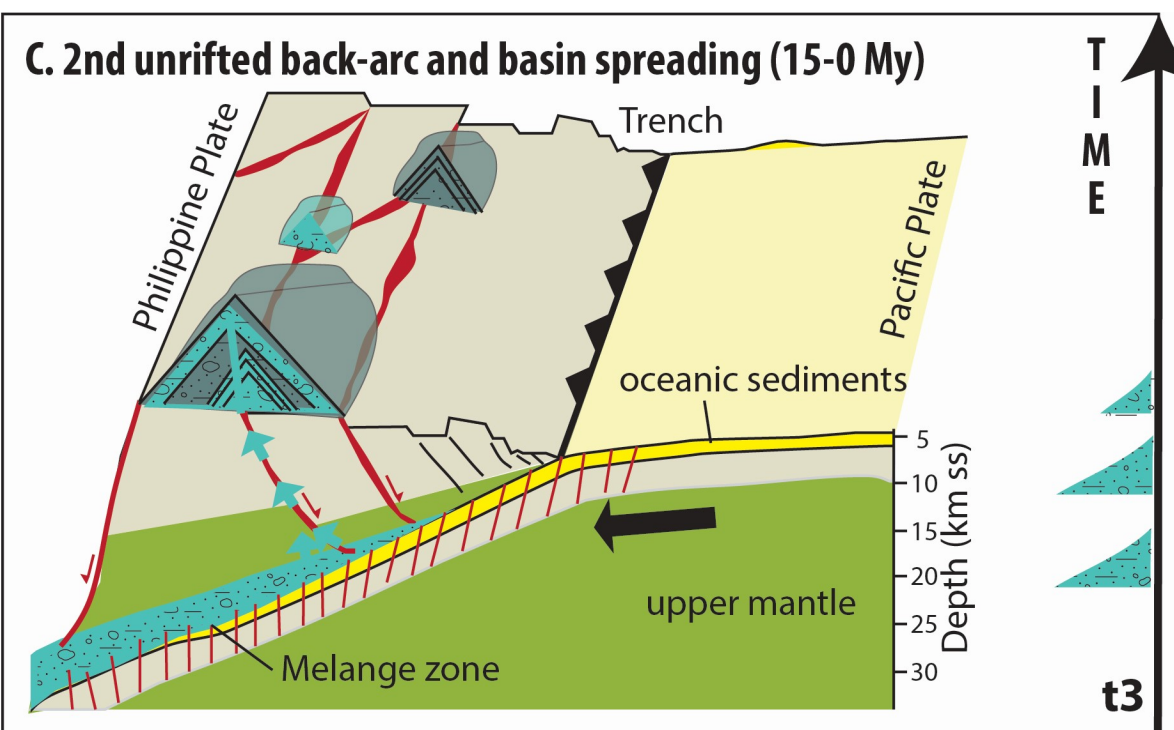

B. 1rst unrifted back-arc and basin spreading (40-15 My)

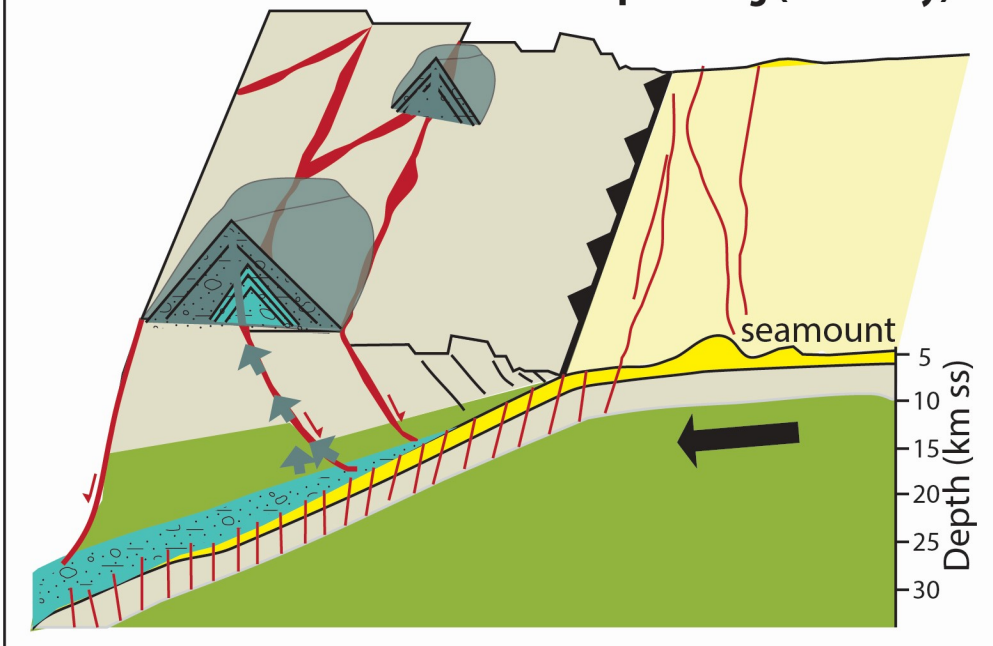

A. Subduction initiation (50-40 My)



320 Figure 9. Spatio-temporal model of episodic fluid circulation and precipitation from the subduction 321 zone up to the mud volcanoes A. Subduction initiation (50-40 My); B. 1rst unrifted back-arc and basin spreading (40-15 My); C. $2^{\text {nd }}$ unrifted back-and basin spreading (15-0My). 


\subsection{Precipitation mechanisms}

The extensional fault system accommodating uplift of the forearc ridge upon which Fantangisña Seamount formed is complex and should imply fault linkage and relay (e.g., Fossen \& Rotevatn, 2016), offering many potential pathways for the fluid and mud circulation through or along the fault segments (Figure 9), depending on the modifications of the fault permeability by triggers such as mud overpressures or earthquakes (Gratier, 2011). As shown by field observations in extensional systems, the highest amount of fluid circulation in a fault system tends to be localized in fault relays, where displacement is transferred across linking structures between two fault segments (Gartrell et al., 2003; Micarelli et al., 2006; Frery et al., 2017).

Serpentine mudflows were at least recorded from Neogene until present day, as attested by, among other indications, Miocene or Pliocene nanofossils sampled in the first hundreds meters cored on Fantangisña seamount flank (U1498A, Fryer et al., 2017), Upper Miocene to Upper Pleistocene serpentine mudflow layers interbedded with sediments on Asùt Tesoru seamount (Kurz et al., 2017) and active serpentinite mudflow and slab-fluid seeps observed at the summit of some of the Mariana forearc mud volcanoes (Fryer et al., 1999, 2006). The episodicity of those events is demonstrated on the flank of Conical Seamount, located about $80 \mathrm{~km}$ west of the Mariana Trench axis. Six units composed of serpentine mud flows were recorded from $300 \mathrm{~m}$ of drilling (hole 779A, LEG 125, Fryer \& Mottl, 1992). Each unit is composed of a sequence of pulses ranging from a few tens of meters to a few centimetres, indicating variable volumes and rates of episodic serpentine mudflow events from Lower Pliocene to Holocene (Fryer et al., 1989). Those serpentine mudflows are likely to be related to the activity of at least two major faults intersecting below Conical Seamount (Fryer et al., 1992). Pelagic sediments capping 
347 the mudflows (Fryer et al., 1989) seem to indicate periods with no mud volcanism activity

348 and can be related to a decrease in inter-seismic fault permeability by gouge compaction

349 and fracture healing and sealing (Renard et al., 2000; Gratier et al., 2009; Gratier, 2011).

350 However, the duration of those periods is difficult to evaluate given the thinness of the

351 pelagic layers.

\subsection{Origin of the fluid and potential trigger event}

"The Marianna mud volcanos are dynamic and erupts episodically. In this study, we observed episodes of fluid circulation/precipitation in open fractures from Late Cretaceous to $8.2 \mathrm{My}(+/-3.4 \mathrm{My})$. Those circulation events are now embedded in the mud and (i) can be or (ii) not be related to the mud volcanism. Several events of mud volcanism have been identified in the literature from Eocene to present day. The upper serpentinite mud layers cored on the flank of Fantangisña seamount lay above pelagic sediments that are upper Miocene, dating the youngest mud volcanism event recorded in this seamount in the range of 10 My (Menapace et al., 2019). Other holes showed that Asut Tesoru Seamount may have been active since the Eocene, based on analysis of two serpentine-bearing ( $\sim 50 \%$ serpentine) sediment intervals immediately above Eocene basement recovered during Deep Sea Drilling Project (DSDP) Leg 60 at Site 459 (Despraires, 1981; Fryer et al., 2017). Those event have been onserved in the shallowes mud layers of the mud volcanoes that the ocean drilling program was able to drill and, given the thickness of the mud volcanos it is highly probable that the mud volcanism started early in the subduction process.

The muds in a given eruptive state may reflect a complicated mixture of materials from the deep subduction channel plus the addition of materials emplaced in the shallower conduit region during previous eruptions Differences in Sr isotopic signatures from this study samples permit the distinction from the different sources. The results show that sample A5 has relative less radiogenic strontium ratio comparing to the other samples' IODP references (A1, A7 and D5 - Table 4). This less radiogenic Sr value can reflect a 
greater proportion of contribution from the mantle components. According to the literature (Pearce et al., 1995; Han et al., 1997) mantle components are depleted in Sr during the fractional crystallization of the magma. This suggestion corroborates the carbonate precipitation at greater depth, before/ during the exhumation

The sub-parallel elongated minerals (Figure 4) could indicate crystallisation under stress (e.g., Bons \& Montenari, 2005; Gratier et al., 2012). The fan-shaped calcium carbonate minerals could indicate the precipitation of a free fluid in an open fracture, either resulting from a primary circulation event or previous dissolution episodes (Billi et al., 2007), as supported by the occurrence of both mineralisation types within an individual displaced vein and the occurrence of stylolite features (Figure 4). However, sample D5 is coming from drill hole 1498A whereas the other samples are from the hole 1498B. The current pore fluids' PH as well as the Mg and silica contents differ between those two holes (Fryer et al., 2018) and can potentially influence the type and rate of carbonate precipitation.

The progressive silicification of the carbonate veins (Figure 3) could indicate a low-temperature, structure-controlled event (Auclair et al., 1993; Akbulut et al., 2006) as well as a change in $\mathrm{pH}$, a variation in composition of the same fluid due to fluid/wall rock interaction or to two separate fluid influxes (Uçurum et al., 1996; Uçurum, 2000). The UCC-normalized LREEs pattern (Figure 6), ${ }^{87} \mathrm{Sr} /{ }^{86} \mathrm{Sr}$ ratios ranging from 0.704977 to 0.705798 (Table 4 ) and $\delta^{18} \mathrm{O}$ values of 18.7 to 19.8 (\%o, V-SMOW) (Figure 7) of this study's carbonate veins indicate a mixed origin of the precipitated fluids, influenced by interaction with the surrounding serpentinite mudflow material, as the ${ }^{87} \mathrm{Sr} /{ }^{86} \mathrm{Sr}$ values inthe pore fluids ranges from 0.70495 to 0.70585 at Fantangisña, seamount and from 0.70523 to 0.70538 in Metavolcanic material (Albers et al., 2019; Figure 7). The veins could have recorded several precipitation stages, from fluids with a mantle signature at the slab depth to a mix of shallow hydrothermal fluids and seawater close to the seafloor within 
the mud volcano. The UCC-normalized LREE pattern and the high degree of silicification of

the oldest veins (A5, Figure 8) are comparable with other studies (Albers et al., 2019) and

401 support the hypotheses of an early precipitation during the convergence processes

402 followed by diagenetic processes during the exhumation and contact with the serpentinite mud, within the subduction channel mélange zone and/or within the mud volcano edifice.

Considering a mean carbonate $\delta^{18} \mathrm{O}$ signature of $19 \%$, V-SMOW) and Fantangisña seamount water's $\delta^{18} \mathrm{O}$ signature of $0 \%$, V-SMOW (Debret et al., 2019), we can compute from Epstein et al. (1953) a mean precipitation temperature of $100.7^{\circ} \mathrm{C}$ supporting an early diagenesis process. Debret et al., 2019 discuss the serpentinization process and estimate a

409 calculated estimated temperatures of carbonate formation below $100{ }^{\circ} \mathrm{C}$ and shifted those 410 value to 130 to $175^{\circ} \mathrm{C}$ and 220 to $310^{\circ} \mathrm{C}$ as to account for the conditions of precipitation at 411 depth, below the mud volcanoes, that are inferred to be the location of formation of the 412 carbonate veins.

413 The early stage of silicification of the younger veins (A1,Figure 8) and the partial match 414 between UCC-normalized LREE pattern (only the LREE 6 elements, Figure 8) and the Pacific 415 deep water profile could indicate a short residence time in shallow conditions, within the 416 mud volcano edifice. Those veins are deformed in a cataclasite structure, previously 417 interpreted as a record of the early exhumation stages within the normal fault system 418 deeply rooted in the subduction channel mélange zone (Fryer et al., 2018). However, the 419 UCC-normalized HREEs pattern and the ${ }^{87} \mathrm{Sr} /{ }^{86} \mathrm{Sr}$ ratios still support a precipitation at 420 greater depth, before/ during the exhumation. Modelling studies showed that the 421 Mariana mud volcanoes spread laterally from a central conduit (Oakley et al., 2008). Those 422 observations tend to support the opening of potential secondary faults within the mud 

431 (Vidal \& Merle, 2000).

volcanoes that can directly drive the uprising material to the flanks of the volcanoes

(Figure 9). The carbonate vein ages spread over tens of million years (Figure 8) supporting the existence of episodic serpentine mud eruptions from depth up to the subsurface or up to the surface of the mud volcanoes. The main conduit can be obstructed during non-activity periods and secondary circulation pathways could be triggered by overpressure, as recorded in travertine structures (Frery et al., 2015), or a normal faulting event at the base of the volcano, opening a high-angle pathway toward the edifice or an upturning fault toward the flank of the edifice as modelled in the case of stratovolcanoes

\section{Conclusions}

433 Serpentinite mud volcanoes' carbonate veins can be dated with U-Pb absolute dating by 434 laser-ablation, providing a history of fluid precipitation in a brittle system from at least the 435 early exhumation stages to edifice building.

436 We propose a rapid exhumation process and formation of the youngest carbonate veins 437 on the flank of the mud volcanoes. Those edifices are episodically active during 438 development of the forearc fault system. This is expressed by a complex fault system 439 preserved within the edifice, with secondary flank faults (such as those indicated on the 440 west side of Fantangisña Seamount) potentially used by the uprising serpentinite mud 441 instead of or simultaneously with the central conduit.

443 Supplementary Materials: The rare earth elements, isotopes and dating raw datasets are 444 available as supplementary material 
445 Acknowledgments: We acknowledge funding from IODP and the Australian IODP Office

446 - our results depend on IODP's scientific ocean drilling and Australian/NZ support of this

447 program and the Austrian Science Fund (FWF-P 31683-N29). The authors also would like

448 to thank Dr. Susanne Schmid and Michael Verrall from CSIRO for their advises and help

449 on the petrological analyses.

References Fluid-rock interactions in the shallow Mariana forearc: carbon cycling and redox conditions. Solid earth, 10(3), 907-930.

Alibo, D.S., \& Nozaki, Y. (1999). Rare Earth Elements in Seawater: Particle Association,

Shale-Normalization, and Ce Oxidation. Geochimica et Cosmochimica Acta 63 (3-4):

Auclair, M., Gauthier, M., Trottier, J., Jebrak, M., \& Chartrand, J. (1993). Mineralogy, Geochemistry, and Paragenesis of the Eastern Metals Serpentinite-Associated Ni-Cu-Zn Deposit, Quebec Appalachians. Economic Geology 88 (1): 123-38. 
for submission to Marine Geology

Bons, P.D., \& Montenari, M. (2005). The Formation of Antitaxial Calcite Veins with Well-Developed Fibres, Oppaminda Creek, South Australia. Journal of Structural Geology 27 (2): 231-48.

Byerlee, J. (1990). Friction, Overpressure and Fault Normal Compression. Geophysical Research Letters 17 (12): 2109-12.

Childs, C., Sylta, Ø., Moriya, S., Morewood, N., Manzocchi, T., Walsh, J.J., \& Hermanssen, D. (2009). Calibrating Fault Seal Using a Hydrocarbon Migration Model of the Oseberg Syd Area, Viking Graben. Marine and Petroleum Geology 26 (6): 764-74.

Coplen, T.B. (1995). Discontinuance of SMOW and PDB. Nature 375 (6529): 285.

Debret, B., Albers, E., Walter, B., Price, R., Barnes, J.D., Beunon, H., Facq, S., Gillikin, D.P., Mattielli, N., \& Williams, H. (2019). Shallow Forearc Mantle Dynamics and Geochemistry: New Insights from IODP Expedition 366. Lithos 326: 230-45.

Desprairies, A., 1982. Authigenic minerals in volcanogenic sediments cored during Deep Sea Drilling Project Leg 60. In Hussong, D.M., Uyeda, S., et al., Initial Reports of the Deep Sea Drilling Project, 60: Washington, DC (U.S. Government Printing Office), 455-466. http://dx.doi.org/10.2973/dsdp.proc.60.120.1982

Dockrill, B., \& Shipton, Z.K. (2010). Structural Controls on Leakage from a Natural CO2 Geologic Storage Site: Central Utah, USA. Journal of Structural Geology 32 (11): $1768-82$.

Douville, E., Charlou, J.L., Oelkers, E.H., Bienvenu, P., Jove Colon, C.F., Donval, J.P., Fouquet, Y., Prieur, D., \& Appriou, P. (2002). The Rainbow Vent Fluids (36 14' N, MAR): The Influence of Ultramafic Rocks and Phase Separation on Trace Metal Content in Mid-Atlantic Ridge Hydrothermal Fluids. Chemical Geology 184 (1-2): $37-48$. 
Epstein, E., Samuel, W., et al. "Revised carbonate-water isotopic temperature scale." Geological Society of America Bulletin 64.11 (1953): 1315-1326.Faulkner, D.R., \& Rutter, E.H. (2001). Can the Maintenance of Overpressured Fluids in Large Strike-Slip Fault Zones Explain Their Apparent Weakness? Geology 29 (6): 503-6.

Fossen, H., \& Rotevatn, A. (2016). Fault Linkage and Relay Structures in Extensional Settings-A Review. Earth-Science Reviews 154: 14-28.

Frery, E., Gratier, J.P., Ellouz-Zimmerman, N., Deschamps, P., Blamart, D., Hamelin, B., \& Swennen, R. (2017). Geochemical Transect through a Travertine Mount: A Detailed Record of CO2-Enriched Fluid Leakage from Late Pleistocene to Present-Day-Little Grand Wash Fault (Utah, USA). Quaternary International 437: 98-106.

Frery, E., Gratier, J.P., Ellouz-Zimmerman, N., Loiselet, C., Braun, J., Deschamps, P., Blamart, D., Hamelin, B., \& Swennen, R. (2015). Evolution of Fault Permeability during Episodic Fluid Circulation: Evidence for the Effects of Fluid-rock Interactions from Travertine Studies (Utah-USA). Tectonophysics 651: 121-37.

Fryer, P., Mottl, M.J. (1992). Lithology, Mineralogy, and Origin of Serpentine Muds Recovered from Conical and Torishima Forearc Seamounts: Results of Leg 125 Drilling. In Fryer, P., Pearce, J.A., Stokking, L.B., et Al., Proc. ODP, Sci. Results, 125. College $\begin{array}{llll}\text { Station, } & \text { TX } \quad \text { (Ocean }\end{array}$ https://doi.org/10.2973/odp.proc.sr.125.126.1992.

Fryer, P., Wheat, G., Williams, T., and the Expedition 366 Scientists (2017). Expedition 366 Preliminary Report: Mariana Convergent Margin and South Chamorro Seamount. International Ocean Discovery Program, https://doi.org/10.14379/iodp.pr.366.2017. 
512

513

514

515

Fryer, P., \& Salisbury, M.H. (2006). Leg 195 Synthesis: Site 1200-Serpentinite Seamounts of the Izu-Bonin/Mariana Convergent Plate Margin (ODP Leg 125 and 195 Drilling Results). In Proc. ODP, Sci. Results, 195:1-30.

Fryer, P., Gharib, J., Ross, K., Savov, I., \& Mottl, M.J. (2006). Variability in Serpentinite Mudflow Mechanisms and Sources: ODP Drilling Results on Mariana Forearc Seamounts. Geochemistry, Geophysics, Geosystems 7 (8).

Fryer, P., Saboda, K.L., Johnson, L.E., Mackay, M.E., Moore, G.F., \& Stoffers, P. (1990). Conical Seamount: SeaMARC II, Alvin Submersible, and Seismic Reflection Studies. In Proc. Ocean Drill. Program Sci. Results, 125:3-11.

Fryer, P., Pearce, J.A., \& Stokking, L.B. (1992). 36. A Synthesis of Leg 125 Drilling of Serpentine Seamounts on the Mariana and Izu-Bonin Forearcs. In Proceedings of the Ocean Drilling Program, Scientific Results, 125:593-614.

Fryer, P., Pearce, J.A., \& ODP Leg and Shipboard Party (1989). ODP Leg 125 Drills Forearc Crust, Mantle. Geotimes 34 (7): 18-20.

Fryer, P., Wheat, C.G., \& Mottl., M.J. (1999). Mariana Blueschist Mud Volcanism: Implications for Conditions within the Subduction Zone. Geology 27 (2): 103-6.

Fryer, P., Wheat, C.G., Williams, T., and the Expedition 366 Scientists (2018). Proceedings of the International Ocean Discovery Program Volume 366 publications.iodp.org. https://doi.org/10.14379/iodp.proc.366supp.2018

Fryer, P., Wheat, C. G., Williams, T., Kelley, C., Johnson, K., Ryan, J., ... \& Debret, B. (2020). Mariana serpentinite mud volcanism exhumes subducted seamount materials: implications for the origin of life. Philosophical Transactions of the Royal Society A, 378(2165), 20180425. 
for submission to Marine Geology

Funnell, M.J., Peirce, C., \& Robinson, A.H. (2017). Structural Variability of the Tonga-Kermadec Forearc Characterized Using Robustly Constrained Geophysical Data. Geophysical Journal International 210 (3): 1681-1702.

Gartrell, A., Zhang, Y., Lisk, M., \& Dewhurst, D. (2003). Enhanced Hydrocarbon Leakage at Fault Intersections: An Example from the Timor Sea, Northwest Shelf, Australia. Journal of Geochemical Exploration 78: 361-65.

Gratier, J.P. (2011). Fault Permeability and Strength Evolution Related to Fracturing and Healing Episodic Processes (Years to Millennia): The Role of Pressure Solution. Oil \& Gas Science and Technology-Revue d'IFP Energies Nouvelles 66 (3): 491-506.

Gratier, J.P., Favreau, P., Renard, F., \& Pili, E. (2002). Fluid Pressure Evolution during the Earthquake Cycle Controlled by Fluid Flow and Pressure Solution Crack Sealing. Earth, Planets and Space 54 (11): 1139-46.

Gratier, J.P., Frery, E., Deschamps, P., Røyne, A., Renard, F., Dysthe, D., Ellouz-Zimmerman, N., \& Hamelin, B. (2012). How Travertine Veins Grow from Top to Bottom and Lift the Rocks above Them: The Effect of Crystallization Force. Geology 40 (11): 1015-18.

Gratier, J.P., Guiguet, R., Renard, F., Jenatton, L., \& Bernard, D. (2009). A Pressure Solution Creep Law for Quartz from Indentation Experiments. Journal of Geophysical Research: Solid Earth 114 (B3).

Han, B. F., Wang, S. G., Jahn, B. M., Hong, D. W., Kagami, H., \& Sun, Y. L. (1997). Depleted-mantle source for the Ulungur River A-type granites from North Xinjiang, China: geochemistry and $\mathrm{Nd}-\mathrm{Sr}$ isotopic evidence, and implications for Phanerozoic crustal growth. Chemical Geology, 138(3-4), 135-159.

Hansman, R.J., Albert, R., Gerdes, A., \& Ring, U. (2018). Absolute Ages of Multiple Generations of Brittle Structures by U-Pb Dating of Calcite. Geology 46 (3): 207-10. 
Ito, E., \& Stern, R.J. (1986). Oxygen-and Strontium-Isotopic Investigations of Subduction Zone Volcanism: The Case of the Volcano Arc and the Marianas Island Arc. Earth and Planetary Science Letters 76 (3-4): 312-20.

Jiang, Z., Sun, Z., Liu, Z., Cao, H., Geng, W., Xu, H., \& Wang, L. (2018). Rare-Earth Element Geochemistry Reveals the Provenance of Sediments on the Southwestern Margin of the Challenger Deep. Journal of Oceanology and Limnology, 1-12.

Kodolányi, J., Pettke, T., Spandler, C., Kamber, B.S., \& Gméling, K. (2011). Geochemistry of Ocean Floor and Fore-Arc Serpentinites: Constraints on the Ultramafic Input to Subduction Zones. Journal of Petrology 53 (2): 235-70.

Kbulut, M., Pişkin, Ö., \& Karayiğit, A.I. (2006). The Genesis of the Carbonatized and Silicified Ultramafics Known as Listvenites: A Case Study from the Mihalıççık Region

Kurz, W., Micheuz, P., Grunert, P., Auer, G., \& Reuter, M. (2017). Seamount Subduction and Serpentinite Mud Volcanisms in the Mariana Convergent Margin System: Time Constraints from Micropaleontological Studies (IODP Expedition 366). In AGU Fall Meeting Abstracts.

Liyan, T., Guangtao, Z., \& Zuolin, C. (2003). The Preliminary Study of Petrological Geochemistry of Basalts from Hydrothermal Activity Regions, Mariana Trough. Journal-ocean university of qingdao, Chinese edition 33 (3): 405-12.

Menapace, W., Tangunan, D., Maas, M., Williams, T., \& Kopf, A. (2019). Rheology and biostratigraphy of the Mariana serpentine muds unravel mud volcano evolution. Journal of Geophysical Research: Solid Earth, 124(11), 10752-10776. 
Micarelli, L., Moretti, I., Jaubert, M., \& Moulouel, H. (2006). Fracture Analysis in the South-Western Corinth Rift (Greece) and Implications on Fault Hydraulic Behavior. Tectonophysics 426 (1-2): 31-59.

Mrozowski, C.L., \& Hayes, D.E. (1980). A Seismic Reflection Study of Faulting in the Mariana Fore Arc. The Tectonic and Geologic Evolution of Southeast Asian Seas and Islands, 223-34.

Nuriel, P., Weinberger, R., Kylander-Clark, A.R.C., Hacker, B.R., \& Craddock, J.P. (2017). The Onset of the Dead Sea Transform Based on Calcite Age-Strain Analyses. Geology 45 (7): 587-90.

Oakley, A.J., Taylor, B., \& Moore, G.F. (2008). Pacific Plate Subduction beneath the Central Mariana and Izu-Bonin Fore Arcs: New Insights from an Old Margin. Geochemistry, Geophysics, Geosystems 9 (6).

Paton, C., Woodhead, J.D., Hellstrom, J.C., Hergt, J.M., Greig, A., \& Maas, R. (2010). Improved Laser Ablation U-Pb Zircon Geochronology through Robust Downhole Fractionation Correction. Geochemistry, Geophysics, Geosystems 11 (3).

Pearce, J. A., Baker, P. E., Harvey, P. K., \& Luff, I. W. (1995). Geochemical evidence for subduction fluxes, mantle melting and fractional crystallization beneath the South Sandwich island arc. Journal of Petrology, 36(4), 1073-1109

Renard, F., Gratier, J.P., \& Jamtveit, B. (2000). Kinetics of Crack-Sealing, Intergranular Pressure Solution, and Compaction around Active Faults. Journal of Structural Geology 22 (10): 1395-1407.

Rice, J.R. (1992). Fault Stress States, Pore Pressure Distributions, and the Weakness of the San Andreas Fault. In International Geophysics, 51:475-503. Elsevier. 
604 Ring, U., \& Gerdes, A. (2016). Kinematics of the Alpenrhein-Bodensee Graben System in the Central Alps: Oligocene/Miocene Transtension Due to Formation of the Western Alps Arc. Tectonics 35 (6): 1367-91. https://doi.org/10.1002/2015TC004085.

Roberts, N.M.W., \& Walker, R.J. (2016). U-Pb Geochronology of Calcite-Mineralized Faults: Absolute Timing of Rift-Related Fault Events on the Northeast Atlantic Margin. Geology 44 (7): 531-34. https://doi.org/10.1130/G37868.1.

Salisbury, M.H., Shinohara, M., Richter, C., Araki, E., Barr, S.R., D’Antonio, M., Dean, S.M., Drill. Program Initial Rep, 22-32.

Sibson, R.H. (1994). Crustal Stress, Faulting and Fluid Flow. Geological Society, London, Special Publications 78 (1): 69-84.

Sleep, N.H., \& Blanpied, M.L. (1994). Ductile Creep and Compaction: A Mechanism for Transiently Increasing Fluid Pressure in Mostly Sealed Fault Zones. Pure and Applied Geophysics 143 (1-3): 9-40.

Stern, R.J. (2004). Subduction Initiation: Spontaneous and Induced. Earth and Planetary Science Letters 226 (3-4): 275-92.

Taylor, S.R., \& McLennan, S.M. (1995). The Geochemical Evolution of the Continental Crust. Reviews of Geophysics 33 (2): 241-65.

Taylor, S.R., \& McLennan, S.M. (1985). The Continental Crust: Its Composition and Evolution. Blackwell Scientific Publications, 312pp. Clinopyroxene as a Recorder of Magma History, Eruption Triggers, and Ascent Rates. Geochimica et Cosmochimica Acta 251: 265-83. 
Uçurum, A. (2000). Listwaenites in Turkey: Perspectives on Formation and Precious Metal Concentration with Reference to Occurrences in East-Central Anatolia. Ofioliti 25 (1): 15-29.

Uçurum, A, Larson, L.T., \& Boztug, D. (1996). Geology, Geochemistry, and Petrology of the Alkaline Subvolcanic Trachyte-Hosted Iron Deposit in the Karakuz Area, Northwestern Hekimhan-Malatya, Turkey. International Geology Review 38 (11): 995-1005.

Uyeda, S., \& Kanamori, H. (1979). Back-arc Opening and the Mode of Subduction. Journal of Geophysical Research: Solid Earth 84 (B3): 1049-61.

Uysal, I.T., Feng, Y., Zhao, J., Bolhar, R., Işik, V., Baublys, K.E., Yago, A., \& Golding, S.D. (2011). Seismic Cycles Recorded in Late Quaternary Calcite Veins: Geochronological, Geochemical and Microstructural Evidence. Earth and Planetary Science Letters 303 $(1-2): 84-96$.

Uysal, I.T. Feng, Y., Zhao, J., Altunel, E., Weatherley, D., Karabacak, V., Cengiz, O., Golding, S.D., Lawrence, M.G., \& Collerson, K.D. (2007). U-Series Dating and Geochemical Tracing of Late Quaternary Travertine in Co-Seismic Fissures. Earth and Planetary Science Letters 257 (3-4): 450-62.

Vidal, N., \& Merle, O. (2000). Reactivation of Basement Faults beneath Volcanoes: A New Model of Flank Collapse. Journal of Volcanology and Geothermal Research 99 (1-4): $9-26$.

Vignaroli, G., Berardi, G., Billi, A., Kele, S., Rossetti, F., Soligo, M., \& Bernasconi, S.M. (2016). Tectonics, Hydrothermalism, and Paleoclimate Recorded by Quaternary Travertines and Their Spatio-Temporal Distribution in the Albegna Basin, Central Italy: Insights on Tyrrhenian Margin Neotectonics. Lithosphere 8 (4): 335-58. 
650 Wei, X., Xu, Y.G., Feng, Y.X, Zhao., J.X. (2014) Plume-lithosphere interaction in the 651 generation of the Tarim large igneous province, NW China: geochronological and 652 geochemical constraints. Am. J. Sci., 314, pp. 314-356

653 Wheat, C. G., Seewald, J. S., \& Takai, K. (2020). Fluid transport and reaction processes 654 within a serpentinite mud volcano: South Chamorro Seamount. Geochimica et 655 Cosmochimica Acta, 269, 413-428.

656 Woodhead, J., Hellstrom, J., Paton, C., Hergt, J., Greig, A., \& Maas, R. (2008). A Guide to 657 Depth Profiling and Imaging Applications of LA-ICP-MS. Laser Ablation ICP-MS in the $658 \quad$ Earth Sciences: Current Practices and Outstanding Issues 40. 